\section{OPEN ACCESS}

Edited by:

Christopher Edward Cornwall, Victoria University of Wellington,

New Zealand

Reviewed by:

Rutger De Wit,

UMR 9190 Centre Pour la Biodiversité Marine, l'exploitation et la

Conservation, France

Eberhard Gischler

Goethe University Frankfurt, Germany

${ }^{*}$ Correspondence:

Christine M. Lee

christine.m.lee@jpl.nasa.gov

Specialty section:

This article was submitted to Global Change and the Future Ocean,

a section of the journal

Frontiers in Marine Science

Received: 31 December 2020

Accepted: 12 April 2021

Published: 05 May 2021

Citation:

Callejas IA, Lee CM, Mishra DR

Felgate SL, Evans C, Carrias A, Rosado A, Griffin R, Cherrington EA,

Ayad M, Rudresh M, Page BP and

Jay JA (2021) Effect of COVID-19

Anthropause on Water Clarity

in the Belize Coastal Lagoon.

Front. Mar. Sci. 8:648522.

doi: 10.3389/fmars.2021.648522

\title{
Effect of COVID-19 Anthropause on Water Clarity in the Belize Coastal Lagoon
}

\author{
Ileana A. Callejas ${ }^{1}$, Christine M. Lee ${ }^{2 *}$, Deepak R. Mishra ${ }^{3}$, Stacey L. Felgate ${ }^{4,5}$, \\ Claire Evans ${ }^{4}$, Abel Carrias 6 , Andria Rosado ${ }^{7}$, Robert Griffin ${ }^{8}$, Emil A. Cherrington ${ }^{9}$, \\ Mariam Ayad ${ }^{10}$, Megha Rudresh ${ }^{3}$, Benjamin P. Page ${ }^{11}$ and Jennifer A. Jay ${ }^{1}$
}

\begin{abstract}
'Department of Civil and Environmental Engineering, University of California, Los Angeles, Los Angeles, CA, United States, 2 Jet Propulsion Laboratory, California Institute of Technology, Pasadena, CA, United States, ${ }^{3}$ Department of Geography, University of Georgia, Athens, GA, United States, ${ }^{4}$ Ocean Biogeosciences, National Oceanography Centre, Southampton, United Kingdom, ${ }^{5}$ Ocean and Earth Sciences, University of Southampton, Southampton, United Kingdom, ${ }^{6}$ Faculty of Science \& Technology, University of Belize, Belmopan, Belize, ${ }^{7}$ Coastal \& Marine Data Centre, Coastal Zone Management Authority \& Institute, Belize City, Belize, ${ }^{8}$ Department of Atmospheric and Earth Science, University of Alabama in Huntsville, Huntsville, AL, United States, ${ }^{9}$ Earth System Science Center, University of Alabama in Huntsville, Huntsville, AL, United States, ${ }^{10}$ Department of Ocean Sciences, University of California, Santa Cruz, Santa Cruz, CA, United States, ${ }^{11}$ Water Resources Center, University of Minnesota, St. Paul, MN, United States
\end{abstract}

The Coronavirus disease 2019 (COVID-19) pandemic halted human activities globally in multiple sectors including tourism. As a result, nations with heavy tourism, such as Belize, experienced improvements in water quality. Remote sensing technologies can detect impacts of "anthropauses" on coastal water quality. In this study, moderate resolution imaging spectroradiometer (MODIS) satellite data were employed along the Belizean coast to investigate impacts of the COVID-19 shutdown on water quality. The attenuation coefficient at $490 \mathrm{~nm}, K_{d}(490)$, was used as an indicator of water quality, with a lower $K_{d}(490)$ indicating increased water clarity. Four Coastal Management Zones were characterized by marine traffic as high traffic areas (HTAs) and two as low traffic areas (LTAs). Monthly composites for two periods, 2002-2019 (baseline) and 2020 were examined for $K_{d}(490)$. For months prior to the COVID-19 shutdown in Belize, there was generally no significant difference in $K_{d}(490)(p>0.05)$ between 2020 and baseline period in HTAs and LTAs. Through the shutdown, $K_{d}$ was lower in 2020 at HTAs, but not for LTAs. At the LTAs, the $K_{d}(490)$ s observed in 2020 were similar to previous years through October. In November, an unusually active hurricane season in 2020 was associated with decreased water clarity along the entire coast of Belize. This study provides proof of concept that satellite-based monitoring of water quality can complement in situ data and provide evidence of significant water quality improvements due to the COVID-19 shutdown, likely due to reduced marine traffic. However, these improvements were no longer observed following an active hurricane season.

Keywords: diffuse attenuation coefficient, moderate resolution imaging spectroradiometer, remote sensing, water quality, marine traffic, Belize Barrier Reef Reserve System, water clarity 


\section{INTRODUCTION}

The Central American nation of Belize is home to the Belize Barrier Reef Reserve System, the largest barrier reef system in the northern hemisphere and a World Heritage Site (UNESCO, 1996; Cherrington et al., 2010, 2020). Belize's reef system is approximately $250 \mathrm{~km}$ in length, $963 \mathrm{~km}^{2}$ in area, and is located 0.5-80 km offshore between Mexico and Guatemala's borders (Gischler and Hudson, 2004; Baumann et al., 2019; ClaudinoSales, 2019). This reef system contains hundreds of reef patches which developed during the Holocene (Gischler and Hudson, 2004; Eckert et al., 2019). Belize's coral reefs support high levels of biodiversity (Young, 2008), and provide essential ecosystem services such as coastal protection and fisheries (Hoegh-Guldberg et al., 2007), and important economic revenue as tourism is a primary contributor to the economy (Murray, 2020). Since 1998, the main use for Belize's reefs has been identified as tourism and thus the nation must continuously monitor tourism impacts in order to prevent the degradation of the reefs and preserve Belize's competitiveness in ecotourism markets (Gibson et al., 1998; Diedrich, 2007).

The Coronavirus disease 2019 (COVID-19) pandemic caused shifts in the environment and climate due to global lockdowns resulting in a reduction of social and economic activities (Bar, 2020; Rume and Islam, 2020). On March 23, 2020, a mandatory quarantine was placed on Ambergris Caye within Belize followed by a countrywide state of emergency (SoE) declared on March 30, 2020 (Government of Belize Press Office, 2020b; United Nations, 2020a). To limit the spread of COVID-19, Belize closed their borders to international travelers by closing land borders and its international airport (Government of Belize Press Office, 2020a). On October 1, 2020, the reopening phase of Belize's international airport began while expecting 140 travelers on its first day (Government of Belize Press Office, 2020c).

Tourism has declined on a global scale, which can have devastating impacts on local and regional economies. Other observed impacts include a reduction of anthropogenic footprint on natural ecosystems (Bar, 2020). Remote sensing datasets are especially well-positioned to assess these changes by providing a mechanism to observe larger scale responses to these declines in human activity, often referred to as the "anthropause" (Rutz et al., 2020). This is especially important in data-scare regions such as Belize. For example, Landsat-8, Sentinel-2, Sentinel-3, and moderate resolution imaging spectroradiometer (MODIS) have been used to evaluate changes in air quality emissions (Wang and Christopher, 2003; Gupta et al., 2006; Mishra et al., 2021), water clarity (Barnes et al., 2013; Zheng et al., 2016; Kuhn et al., 2019), and coastal/ocean productivity (Ho et al., 2017; Astuti et al., 2018; Caballero et al., 2020). A variety of satellites have been used for impact assessment such as Landsat-8 (Nanda et al., 2020; Patel et al., 2020; Yunus et al., 2020), PlanetScope (Niroumand-Jadidi et al., 2020), Sentinel-2 (Braga et al., 2020; Garg et al., 2020), Sentinel-3 (Cherif et al., 2020; Mishra et al., 2020), and MODIS (Gaiser et al., under revision). Multiple studies report reductions in air, water, and noise pollution due to global lockdown orders. Within the hydrosphere, rivers (Dutta et al., 2020; Garg et al., 2020; Patel et al., 2020), lakes (Yunus et al., 2020), lagoons (Braga et al., 2020; Niroumand-Jadidi et al., 2020), and coastal regions (Cherif et al., 2020; Mishra et al., 2020) experienced improvements in water quality with decreases in turbidity, pollution, and pathogens. Improvements in water quality were attributed to reductions in industrial discharges, boat traffic, and public interactions in general. These anthropogenic activities tend to increase water column turbidity and sediment resuspension in the near-shore environments and diminish water quality in the lagoon. Here, we hypothesize that the COVID-19 lockdowns and the subsequent decline in tourism and marine traffic will improve the water clarity in the Belizean coast, namely near major ports and tourist regions.

To test the hypothesis, we used satellite datasets, model produced runoff and precipitation outputs, and marine traffic data conjunctively to investigate the impacts of the COVID-19 pandemic on coastal water quality in Belize. Using the vertical diffuse attenuation coefficient $\left[K_{d}(490)\right]$ as the primary indicator of water quality, we compared the monthly variations in water clarity in 2020 to that observed from 2002 to 2019.

\section{METHODS}

\section{Study Area and High and Low Marine Traffic Areas}

Belize is located between Mexico and Guatemala with approximately $280 \mathrm{~km}$ of coastline. The climate is tropical with high humidity occurring from June to October. Belize is also on the western side of "Hurricane Alley" with tropical storms and hurricanes appearing from June to November (Morales-Vela et al., 2000). Most of Belize's major cities, towns, tourist centers, and residential properties are located along the coast. The Belizean coastal lagoon is classified as a Case-1 waters like other Caribbean coastal waters (Alvain et al., 2005; Mishra et al., 2005b, 2007; Shi and Wang, 2010) as well as being oligotrophic in nature (Gómez, 2014; Mélin and Vantrepotte, 2015). In addition, multiple studies operate under the knowledge and understanding of these water being oligotrophic (Mendoza et al., 2009; Contreras-Silva et al., 2020; Correa-Ramirez et al., 2020; Guimarais et al., 2021) which is necessary for the development and flourishing of corals (Warne et al., 2005; Guimarais et al., 2021). The Belizean coast hosts multiple diverse ecosystems including coral reefs, mangroves, and seagrasses (Cherrington et al., 2010; Baumann et al., 2016; Verutes et al., 2017; Sweetman et al., 2019; Helmuth et al., 2020) which not only attract tourists but also play an integral role in mitigating coastal erosion and impacts from tropical storms (Cooper et al., 2009). Though these ecosystems contribute millions of United States dollars to Belize's economy (Cooper et al., 2009), industries such as tourism, fisheries, real estate, and agriculture stand to threaten the very ecosystems that allow them to operate (Verutes et al., 2017). Tourism season in Belize takes place during in dry, winter months from November to April (Renaud, 2020).

Belize's Integrated Coastal Zone Management Plan (ICZMP) divides its coast into nine regions based on biological, geographical, economic, and administrative characteristics 


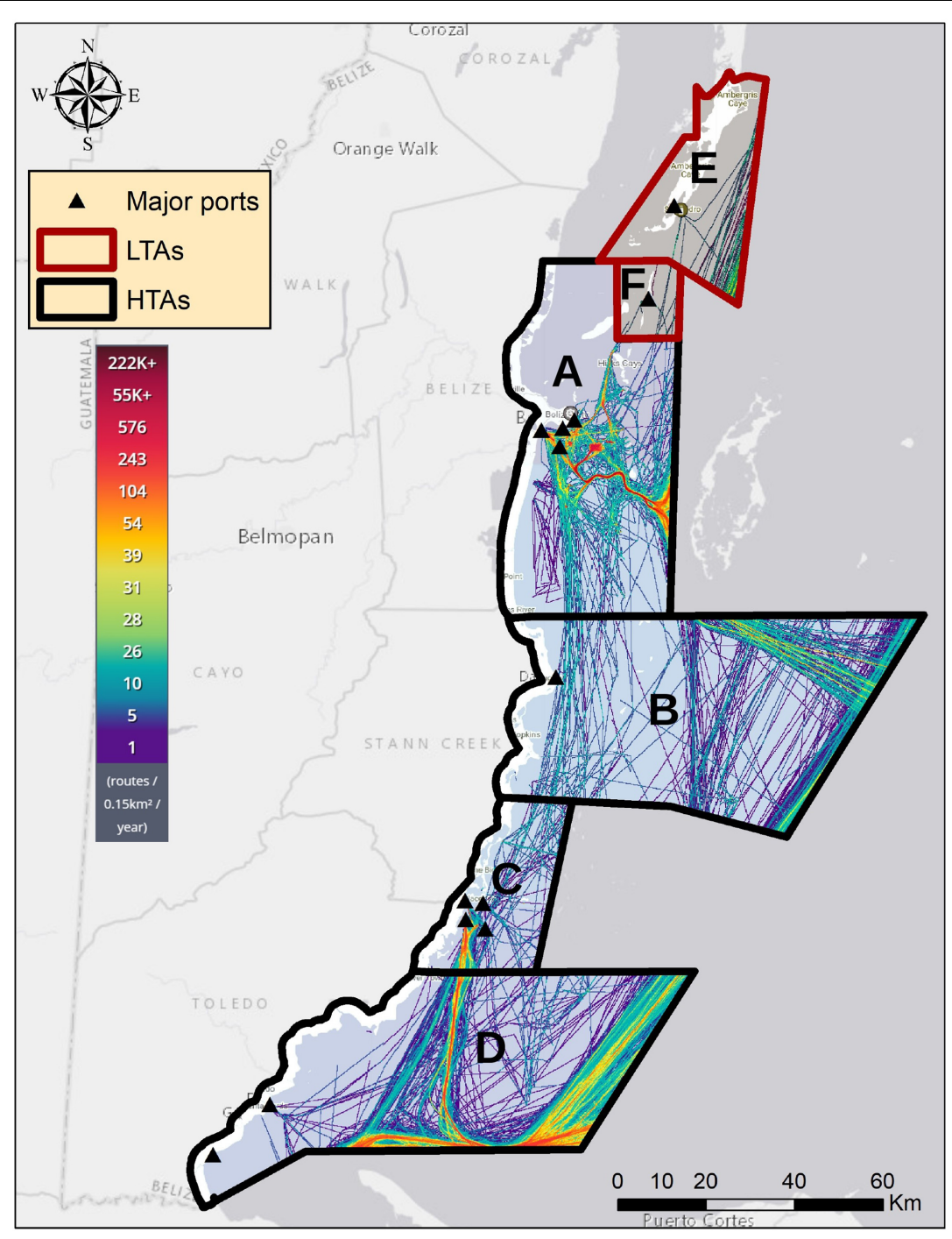

FIGURE 1 | Belize Coastal Zones, Major Ports, and Marine Traffic Density. Six coastal areas were used in this study: (A) Central Region, (B) South Northern Region, (C) South Central Region, (D) Southern Region, (E) Ambergris Caye, and (F) Caye Caulker. Areas (A-D) are denoted as high traffic areas (HTAs) and E \& F as low traffic areas (LTAs). Each zone is filled with 2019 marine traffic density maps where the color of each line corresponds to the number of routes/0.15 km²/year.

(Coastal Zone Management Authority and Institute [CZMAI], 2016). Six of these nine regions were characterized as high and low traffic areas (HTAs and LTAs, respectively) based on a 2019 marine traffic density map assumed to depict typical traffic patterns prior to COVID-related lockdowns (Figure 1). The four HTAs comprise the Central Region which includes Belize City (A), South Northern Region which includes Dangriga (B), part of South Central Region containing Placenia, Big Creek, and Harvest Caye (C), and the Southern Region containing Punta Gorda and Barranco (D). The two LTAs are to the north, at Ambergris Caye (E), and Caye Caulker (F).

\section{High Traffic Areas}

Belize City is the largest city within the Belize District $\left(17.5046^{\circ}\right.$ $\mathrm{N}, 88.1962^{\circ} \mathrm{W}$ ) and is home to the nation's principal port
(Belize City Council, 2020). The Port of Belize Limited is located on the south side of Belize City and is responsible for containerized and break bulk cargo (Belize Port Authority, 2020b). Other major port facilities in Belize City include Puma Energy Bahamas SA for bulk fuel import, Fort Street Tourism Village, a water taxi terminal operated by the Belize Border Management Agency (BMA), Radisson Fort George, and Old Belize port.

Dangriga is a town in southern Belize and the capital of Stann Creek District $\left(16.9696^{\circ} \mathrm{N}, 88.2315^{\circ} \mathrm{W}\right)$. Though the Commerce Bight port 1.5 miles south of Dangriga is currently not operational (Belize Port Authority, 2020a), Dangriga is known as "the cultural capital of Belize" and is a popular tourist location (Belize.com, 2020).

Placencia is located on the Placencia Peninsula $\left(16.5212^{\circ}\right.$ $\left.\mathrm{N}, 88.3713^{\circ} \mathrm{W}\right)$ on the southeast coast of Belize within 
the Stann Creek District and is rapidly growing in tourism (Wells et al., 2014; Renaud, 2020). Just south of the Stann Creek District in the Toledo District is the Port of Big Creek, the nation's second major port (7 News Belize, 2020), responsible for banana exports, crude oil tank farming, and sugar storage (Port of Big Creek, 2020). South of both Big Creek and Placencia and a mile off the coast is Harvest Caye, a private island developed for tourism by a Miami-based Norwegian Cruise Line (Renaud, 2020). Belize City and Placencia are two major coastal cities which have experienced coral growth declines (Baumann et al., 2019) and mangrove clearings (Cherrington et al., 2010).

Punta Gorda $\left(16.0989^{\circ} \mathrm{N}, 88.8095^{\circ} \mathrm{W}\right)$ and Barranco $\left(16.0011^{\circ} \mathrm{N}, 88.9186^{\circ} \mathrm{W}\right)$ are both towns located in the southernmost region of Belize located in the Toledo District. Punta Gorda is the capital of the Toledo District and is home to the Punta Gorda Port (Belize Port Authority, 2020c). The Port of Barranco is a very small port in the town of Barranco (FleetMon, 2020).

\section{Low Traffic Areas}

San Pedro is a town in the southern part of Ambergris Caye in the Belize District in northern Belize $\left(17.9214^{\circ} \mathrm{N}, 87.9611^{\circ} \mathrm{W}\right)$. There is a water taxi terminal with six berths located in San Pedro under the Belize BMA (Belize Port Authority, 2020d).

Caye Caulker is a small island off the coast of Belize $\left(17.7612^{\circ}\right.$ $\mathrm{N}, 88.0277^{\circ} \mathrm{W}$ ) accessible by water taxis and small planes (CayeCaulker.org, 2020).

\section{Satellite Images}

The average vertical diffuse attenuation coefficient for downwelling irradiance at $490 \mathrm{~nm}, K_{d}(490)$, was calculated in Google Earth Engine (GEE) from images collected from MODIS onboard the Aqua satellite. The images processed in GEE started from June 4, 2002 to July 31, 2020. The rest of the images for 2020 were downloaded from https://oceancolor.gsfc.nasa.gov/and ingested into GEE. All images were Level-3 daily images with a spatial resolution of $4 \mathrm{~km}$ and $K_{d}(490)$ was calculated using the NASA operational algorithm (Werdell and Bailey, 2005). The algorithm is a fourth-order polynomial between blue and green remote sensing reflectances $(R r s)$ and $K_{d}(490)$. The algorithm is based on two high quality bio-optical global datasets, the SeaWiFS Bio-Optical Archive and Storage System (SeaBASS) and the NASA bio-Optical Marine Algorithm Data (NOMAD) archives. Though the datasets encompass a broad range of water types and locations, certain oceanic regions remain underrepresented.

The NASA operational algorithm is as follows for the MODIS sensor:

$$
K_{d}(490)=10^{\left(-0.8813-2.0584 x+2.5878 x^{2}-3.4885 x^{3}-1.5061 x^{4}\right)}+0.0166
$$

where $\quad x=\log _{10} \frac{\operatorname{Rrs}(488)}{\operatorname{Rrs}(547)}$. Beside numerous open ocean applications, MODIS-derived $K_{d}(490)$ products have also been used in turbid coastal water (Tomlinson et al., 2019), for coastal river plume characterization during high flow (López et al., 2013), and turbidity impacts on coral health (Freitas et al., 2019; Martínez-Castillo et al., 2020). Caribbean coastal waters are generally considered as Case-1 waters because thriving seagrass and reef habitats help reduce water column turbidity (Mishra et al., 2005a, 2007). The NASA operational algorithm for $K_{d}(490)$ has also been used specifically in coastal Caribbean regions (López et al., 2013; García-Sais et al., 2017; Vega Sequeda et al., 2017). A function was created to calculate $K_{d}(490)$ for each image and the newly calculated band was appended to the image collection. Monthly averages for $K_{d}(490)$ were calculated for the coast of Belize using a mean reducer for LTAs and HTAs and compared between 2020 and the baseline period. The number of pixels included in each monthly calculation was obtained through the count reducer which computes the number of non-null inputs. Percent difference maps of $K_{d}(490)$ were also created in GEE by filtering the images for each respective month of the year, taking the average for the years of 2002-2019 and 2020, and mapping the percent difference between the two time frames. A decrease in $K_{d}(490)$ indicates a decline in water clarity, generally associated with degradation in water quality, whereas an increase in $K_{d}(490)$ indicates an increase in water clarity, associated with an improvement.

\section{Marine Traffic Data}

Marine traffic data were obtained from the company MarineTraffic $^{1}$ for ports and anchorages in Belize from January 2020 to November 2020 (Figure 2). The data uses both Automated Identification System (AIS) data and data from satellite receivers. The data includes arrival and departure data for ports in Belize City, Belize City anchorage, Old Belize, Radisson Fort George, Placencia, Big Creek, Big Creek anchorage, Harvest Caye, San Pedro, and Caye Caulker. The company also detects port calls from Dangriga, Punta Gorda, and Barranco ports, but in 2020 there were no port calls detected through AIS or satellite data for these ports.

\section{Runoff and Precipitation Models}

Monthly time-averaged precipitation and runoff were calculated over Belize using NASA's Modern-Era Retrospective analysis for Research and Applications, Version 2 (MERRA-2) model from June 2002 to October 2020. MERRA-2 is a global atmospheric reanalysis produced by NASA's Global Modeling and Assimilation Office (NASA Global Modeling and Assimilation Office, 2020). For precipitation, the "total surface precipitation" variable was used (M2TMNXFLX v5.12.4) and for runoff, the "overland runoff including throughflow" variable was used (M2TMNXLND v5.12.4). The model outputs were extracted from NASA Giovanni².

\section{Statistical Analysis}

For each month of the year where data were available, data for each location for years 2002-2019 and for the year 2020 were grouped and tested for normality using histograms created in $\mathrm{R}$ ( $\mathrm{R}$ Core Team, 2020). In no cases were both the previous years and 2020 found to be normal, so the Wilcoxon unpaired test was used to test the null hypothesis that there was no difference

\footnotetext{
${ }^{1}$ marinetraffic.com

${ }^{2}$ https://giovanni.gsfc.nasa.gov/giovanni/
} 

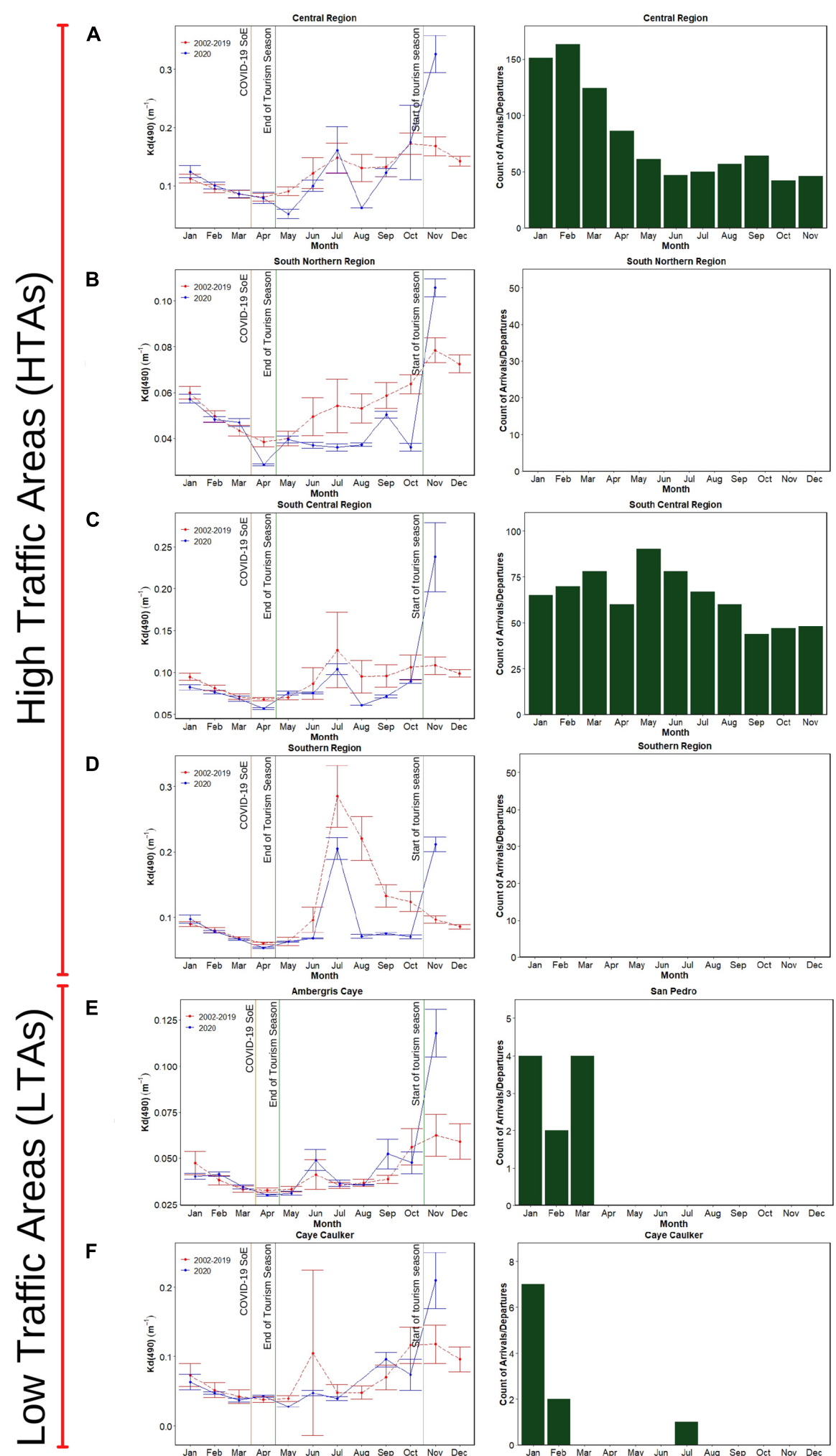

E
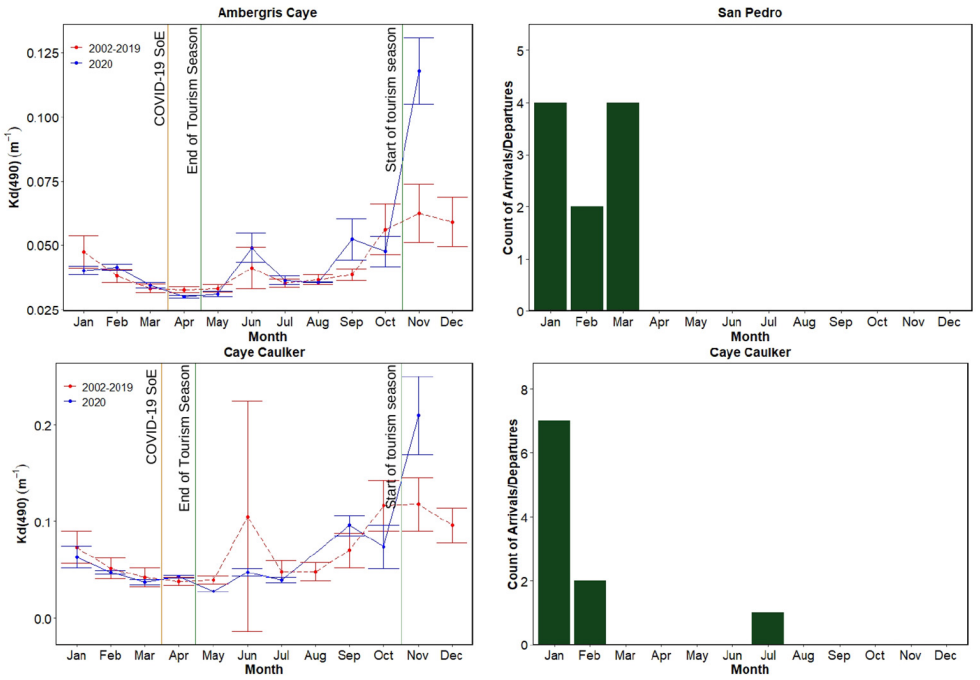

FIGURE 2 | $K_{d}(490)$ Time Series Plots and 2020 Total Port Counts. The first vertical column of figures are plots of monthly $K_{d}(490)$ values and standard deviations for the 2020 and 2002-2019 time periods. The orange vertical line marks the time of the COVID-19 SoE in Belize. The green lines represent the beginning and end of the tourist season in Belize. The second column of figures are total port counts for each month for 2020. Some ports did not have any port calls in 2020 through AIS or satellite data. Each lettered row of plots corresponds to the areas in Figure 1. (A) Central Region, (B) South Northern Region, (C) South Central Region, (D) Southern Region, (E) Ambergris Caye, and (F) Caye Caulker. 

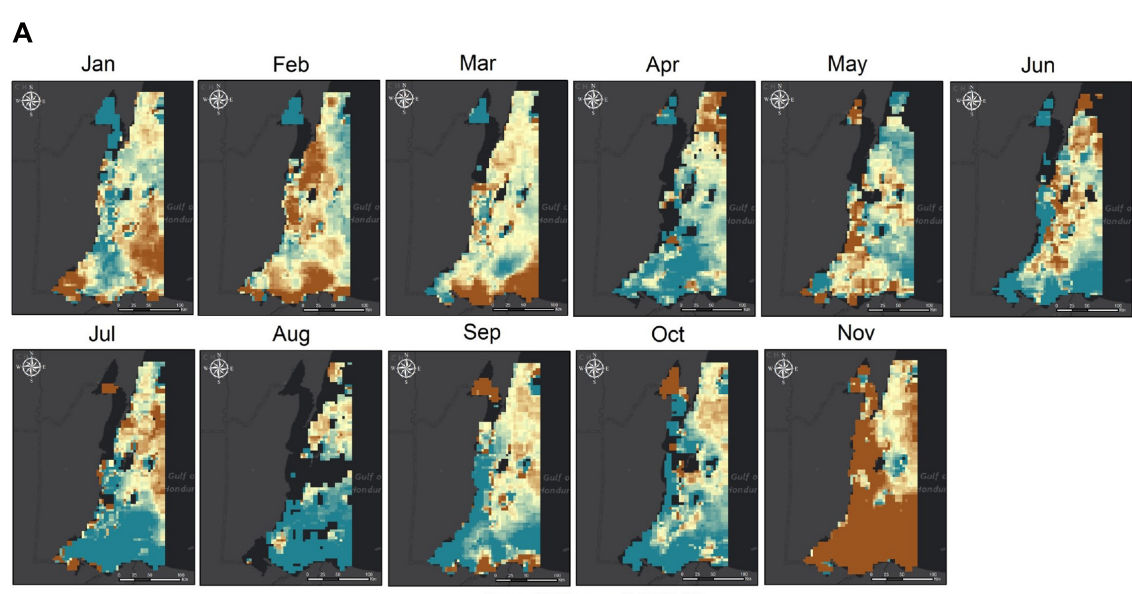

Percent Difference Kd(490) (\%) $\begin{array}{rl}-20 & 0 \\ & 20\end{array}$

B
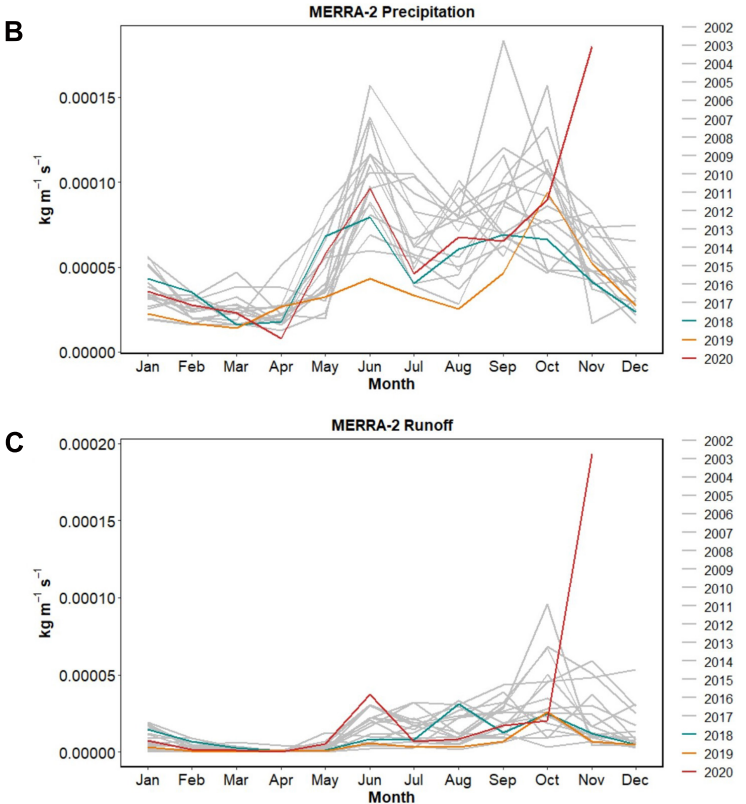

FIGURE 3 | Percent Difference $K_{d}(490)$ Maps and MERRA-2 Model Outputs. (A) Monthly percent difference maps comparing $2020 K_{d}(490)$ values against those of the 2002-2019 (baseline) time period. (B) MERRA-2 precipitation output for the country of Belize from 2002 to 2020 in $\mathrm{kg} \mathrm{m}^{-1} \mathrm{~s}^{-1}$. (C) MERRA-2 runoff output for Belize from 2002 to 2020 in $\mathrm{kg} \mathrm{m}^{-1} \mathrm{~s}^{-1}$.

between 2020 and previous years. We computed means and standard deviation for both time periods.

\section{RESULTS}

At the start of 2020 prior to the Belize SoE COVID shutdown, the $K_{d}(490)$ was consistently similar to that observed for previous years, with no significant differences observed for any location (Figure 2). However, the monthly $K_{d}(490)$ maps show notable decreases in $K_{d}(490)$ along the Belizean coast at HTAs following the initial lockdown orders in place on March 23, 2020 compared to the 2002-2019 average (Figure 3A). Following the SOE in
April, 2020 data showed a lower $K_{d}$ (indicating increased water clarity) compared to previous years in (most) HTAs, but not the LTAs. For example, for HTA-D, which includes Placencia, the average $K_{d}(490)$ from 2002 to 2019 for the month of April was $0.068 \mathrm{~m}^{-1}$ (SD 0.002), while for 2020 the value was $0.057 \mathrm{~m}^{-1}$ (SD 0.001). In May of 2020, HTA-A, which includes Belize's most popular port, shows a $K_{d}$ of $0.051 \mathrm{~m}^{-1}$ (SD 0.008) in 2020, compared to $0.090 \mathrm{~m}^{-1}$ (SD 0.008) for the years 2002-2019. See Table 1 for the $p$-values for hypothesis testing for the difference between 2020 and previous years. While LTAs showed some differences in means, these tended to be smaller, and statistically significant differences were only observed at HTAs. For both HTAs and LTAs for the months of June and July, none of the 
TABLE 1 | Wilcoxon test $p$-values for each month between $K_{d}(490)$ values in 2020 versus 2002-2019 baseline for all regions.

\begin{tabular}{|c|c|c|c|c|c|c|c|c|c|c|c|c|c|}
\hline \multirow[t]{2}{*}{ Site } & \multirow[t]{2}{*}{ Coastal region } & \multirow[t]{2}{*}{ HTA/LTA } & \multicolumn{11}{|c|}{ Wilcoxon test $p$-values } \\
\hline & & & January & February & March & April & May & June & July & August & September & October & November \\
\hline A & Central region & HTA & 0.679 & 0.374 & 0.987 & 0.705 & $0.029^{*}$ & 0.895 & 0.651 & 0.269 & 0.982 & 0.067 & $0.006^{\star}$ \\
\hline$B$ & South Northern region & HTA & 0.806 & 0.866 & 0.164 & $0.018^{\star}$ & 0.429 & 0.988 & 0.479 & 0.250 & 0.83 & $0.006^{\star}$ & $0.033^{\star}$ \\
\hline C & South Central region & HTA & 0.082 & 0.250 & 0.230 & $0.046^{\star}$ & 0.165 & 0.359 & - & 0.113 & $0.004^{*}$ & 0.496 & $<0.001^{*}$ \\
\hline$D$ & Southern region & HTA & 0.600 & 0.968 & 0.423 & 0.483 & 0.063 & 0.403 & 0.852 & $0.044^{*}$ & $0.009^{*}$ & $0.003^{*}$ & $<0.001^{*}$ \\
\hline$E$ & Ambergris Caye & LTA & 0.131 & $0.021^{\star}$ & 0.504 & 0.313 & 0.382 & - & 0.590 & 0.787 & 0.591 & 0.419 & $0.002^{*}$ \\
\hline$F$ & Caye Caulker & LTA & 0.567 & 0.353 & 0.481 & - & - & - & - & - & 0.162 & 0.178 & $0.009^{*}$ \\
\hline
\end{tabular}

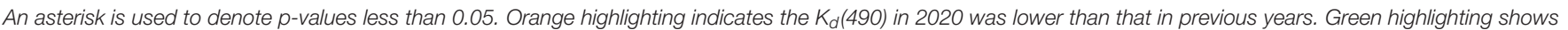
where $K_{d}(490)$ was higher in 2020 than in previous years.

observed differences in means were significant, possibly due to the tourism season ending so no major differences in marine traffic would be expected.

Figure 3A shows the percent difference of $K_{d}(490)$ between 2020 and previous years. A greater fraction of the coastal waters shows a decrease (blue) compared to previous years for the months of April through October. In November 2020, $K_{d}(490)$ increases (brown) drastically across the entire coast. This increase coincides with a record-breaking hurricane season where Belize experienced impacts of Hurricanes Nana, Eta, Iota, and Tropical Storm Cristobal (Amandala Newspaper, 2020). Figures 3B,C show the precipitation and runoff for 2002 through 2020 of Belize. While month to month 2020 was not an atypical year for precipitation through the month of October, both precipitation and runoff were dramatically elevated for the month of November (Figures 3B,C).

Because $K_{d}(490)$ incorporates both inorganic and organic components within the water column, we tested for correlations between in situ chlorophyll-a and MODIS-derived $K_{d}(490)$. Using a dataset from 2018 and 2019, we saw no significant correlation between chlorophyll-a and $K_{d}(490)$ after calculating the Spearman's rank order correlation coefficient following tests for normality using Q-Q plots and histograms (Spearman's rho $=0.34)$ (see Supplementary Material).

\section{DISCUSSION}

This preliminary study shows that MODIS $K_{d}(490)$ data can be used to better understand spatiotemporal changes in water quality impacts associated with environmental disturbances. This is particularly important in locations where in situ data are limited and healthy ecosystems are essential to the local economy. Belize relies on robust tourist traffic to support the economy, and water clarity is critical for coral reef health (De'ath and Fabricius, 2010). Marine traffic due to both commerce and tourism have the potential to result in decreased water clarity through an increase in suspended solids. In addition, marine traffic is also shown to increase nutrient depositions which spurs phytoplankton growth (Zhang et al., 2021). For this site, chlorophyll-a and $K_{d}(490)$ were not significantly associated, suggesting that $K_{d}(490)$ is mainly attributed to sediment resuspension rather than algal particles. Nonetheless, the possible contribution of chlorophyll-a to
MODIS $K_{d}(490)$ at the study site needs further investigation, and future data collection should attempt to deconvolute their signals.

The COVID-19 shutdown in 2020, along with the availability of satellite data with an extended recorded (2002-2019), presented an opportunity to understand the impacts of tourism on water quality and subsequent effects on coral reef health in a data-scarce region. As shown in this work, the COVID19 shutdown resulted in increased water clarity in areas along the Belizean coast with typically high marine traffic, while water clarity was similar in areas with typically low marine traffic during the tourism season. This finding, along with knowledge of the relationships between water clarity and reef health, provides insight on the role of commerce and tourism on the longterm sustainability of the northern hemisphere's largest barrier reef system. Additionally, this finding is similar to other studies that investigated COVID-19 impacts on turbidity, suspended particulate matter (SPM), and total suspended matter (TSM). Studies in India show a 15.9\% decrease in SPM in a lake (Yunus et al., 2020), a significant reduction in the usual pre-monsoon phytoplankton content in coastal waters (Mishra et al., 2020), water quality index increase of $37 \%$ in the Yamuna River (Patel et al., 2020), and reductions in turbidity in the Ganga River (Garg et al., 2020) all with notable changes in April 2020. A couple of studies of the Venice Lagoon, which has high water traffic, found decreases of TSM (Niroumand-Jadidi et al., 2020) and increases in water clarity (Braga et al., 2020) during their lockdowns in March and April 2020.

One expected outcome of this study is a further collaboration with colleagues at the Coastal Zone Management Authority Institute, who is committed to the protection and sustainable management of coastal resources and the ICZMP. The ICZMP is an evidence-based set of policy recommendations that enable an improved understanding of how land management might impact coastal and marine resources (Coastal Zone Management Authority and Institute [CZMAI], 2016).

This work also observes substantial water clarity changes, e.g., anomalous coastal plumes, following the active hurricane season in 2020, an observation enabled by high-frequency, freely available satellite data such as MODIS. Hurricane events in November 2020 coincided with a significant decrease in water clarity compared with November during the baseline period (Aronson et al., 2000; Haines, 2019). Future work should include evaluating the changing climatology of 
hurricane events on corresponding plumes into the marine environment. Furthermore, it is critical that future work considers in situ datasets that would allow improved tuning of remote sensing based estimates of water quality as well as improved characterization of plume constituents. It has been observed that these Belize coastal plumes can be comprised of a variety of constituents, including sediments, agricultural runoff, and sewage (Maidens and Burke, 2005; Macintyre et al., 2009; Emrich et al., 2017; Wells et al., 2019), with Soto et al. (2009) observing a consistent year-to-year river plume occurrences with coral ecosystems (Soto et al., 2009). Though classified as oligotrophic, river plumes can often cause Caribbean waters to become mesotrophic (Warne et al., 2005; Torregroza-Espinosa et al., 2021). In Belize, New River is known to cause a decline in water quality affecting surrounding corals due to poor farming practices and deforestation (Espinoza-Avalos et al., 2009; Reyes et al., 2019). Corals in particular are highly sensitive to changing conditions and it is expected that agricultural runoff and water temperature increases may contribute to their declines (Baumann et al., 2019).

\section{CONCLUSION}

Remote sensing can be used to evaluate these coupled events and their spatial and temporal effects on coastal waters. This study observes an improvement in water clarity during COVID19 shutdowns in Belize, followed by a decline in water clarity following an atypical, active hurricane season. Use of remote sensing is especially important for coastal waters, as populations rise and population density and development along the coasts continue to increase (Martínez et al., 2007; Glavovic, 2017; Elliott et al., 2019). Remote sensing of water quality holds great promise to improve detection of changes in water quality and ecosystem health in data-scarce locations impacted by development, tourism, or climate change, and may represent an asset for nations and entities seeking to set and advance toward the UN Sustainable Development Goals ${ }^{3}$ (United Nations, 2020b). This study in particular is closely linked with SDG 14.1 (life in water). Satellite data can be used to extend ground-based monitoring programs to increase the temporal and spatial density of data. Future research will involve the use of match-ups between in situ and satellite data to further investigate long-term relationships between in situ water quality parameters such as

${ }^{3}$ https://sdgs.un.org/goals/goal14

\section{REFERENCES}

Alvain, S., Moulin, C., Dandonneau, Y., and Bréon, F. M. (2005). Remote sensing of phytoplankton groups in case 1 waters from global SeaWiFS imagery. Deep. Res. Part I Oceanogr. Res. Pap. 52, 1989-2004. doi: 10.1016/j.dsr.2005.06.015

Amandala Newspaper (2020). Record-Breaking 2020 Hurricane Season Ends Today. Available online at: https://amandala.com.bz/news/record-breaking2020-hurricane-season-ends-today/ (accessed December 19, 2020).

Aronson, R. B., Precht, W. F., Macintyre, I. G., and Murdoch, T. J. T. (2000). Coral bleach-out in Belize. Nature 405:36. doi: 10.1038/35011132 chlorophyll-a and TSM and isolate any signal related to COVID19 lockdowns.

\section{DATA AVAILABILITY STATEMENT}

The raw data supporting the conclusions of this article will be made available by the authors, without undue reservation.

\section{AUTHOR CONTRIBUTIONS}

IC, JJ, DM, and CL wrote the manuscript. IC developed all scripts and performed the data processing and analysis with some guidance from BP. CL, DM, RG, and EC conceived the study. CL, JJ, and DM co-advised the research. CL, RG, and JJ acquired the funding. EC, MA, RG, AR, SF, AC, MR, and CE contributed to the development of the project and manuscript editing. All authors contributed to the article and approved the submitted version.

\section{FUNDING}

This work was supported by the NASA RRNES (Grant \#80NSSC20K1746) and NASA ROSES A.8 (cooperative agreement number \#80NSSC19K0200), UCLA's Center for Diverse Leadership in Science, and the Joan Doren Family Foundation. This work was performed in part at the Jet Propulsion Laboratory, California Institute of Technology, under contract with the National Aeronautics and Space Administration.

\section{ACKNOWLEDGMENTS}

We thank Nicole Auil Gomez, Phillips Myles, and Alexander Tewfik (Wildlife Conservation Society, Belize), Clara Wheelock (University of Georgia) for their support during the project.

\section{SUPPLEMENTARY MATERIAL}

The Supplementary Material for this article can be found online at: https://www.frontiersin.org/articles/10.3389/fmars. 2021.648522/full\#supplementary-material

Astuti, I. S., Mishra, D. R., Mishra, S., and Schaeffer, B. (2018). Spatio-temporal dynamics of inherent optical properties in oligotrophic northern Gulf of Mexico estuaries. Cont. Shelf Res. 166, 92-107. doi: 10.1016/j.csr.2018.06.016

Bar, H. (2020). COVID-19 lockdown: animal life, ecosystem and atmospheric environment. Environ. Dev. Sustain. doi: 10.1007/s10668-020-01002-7 [Epub ahead of print].

Barnes, B. B., Hu, C., Schaeffer, B. A., Lee, Z., Palandro, D. A., and Lehrter, J. C. (2013). MODIS-derived spatiotemporal water clarity patterns in optically shallow Florida Keys waters: a new approach to remove bottom contamination. Remote Sens. Environ. 134, 377-391. doi: 10.1016/j.rse.2013.03.016 
Baumann, J. H., Ries, J. B., Rippe, J. P., Courtney, T. A., Aichelman, H. E., Westfield, I., et al. (2019). Nearshore coral growth declining on the Mesoamerican Barrier Reef System. Glob. Chang. Biol. 25, 3932-3945. doi: 10.1111/gcb.14784

Baumann, J. H., Townsend, J. E., Courtney, T. A., Aichelman, H. E., Davies, S. W., Lima, F. P., et al. (2016). Temperature regimes impact coral assemblages along environmental gradients on lagoonal reefs in Belize. PLoS One 11:e0162098. doi: 10.1371/journal.pone.0162098

Belize City Council (2020). About Belize City. Available online at: https://web.archive.org/web/20140723140609/http://belizecitycouncil.org/ about-belize-city (accessed December 17, 2020).

Belize.com (2020). Stann Creek Belize - Home Of Culture Capital Dangriga. Available online at: https://belize.com/stann-creek/ (accessed December 30, 2020).

Belize Port Authority (2020a). Commerce Bight. Available online at: https:// www.portauthority.bz/port-facilities/commerce-bight/ (accessed December 30, 2020).

Belize Port Authority (2020b). Port Facilities. Available online at: https://www. portauthority.bz/port-facilities/ (accessed December 17, 2020).

Belize Port Authority (2020c). Punta Gorda Port. Available online at: https: //www.portauthority.bz/port-facilities/punta-gorda-port/ (accessed December 30, 2020).

Belize Port Authority (2020d). San Pedro Terminal. Available online at: https:// www.portauthority.bz/port-facilities/san-pedro-terminal/ (accessed December 30, 2020).

Braga, F., Scarpa, G. M., Brando, V. E., Manfè, G., and Zaggia, L. (2020). COVID-19 lockdown measures reveal human impact on water transparency in the Venice Lagoon. Sci. Total Environ. 736:612. doi: 10.1016/j.scitotenv.2020.139612

Caballero, I., Fernández, R., Escalante, O. M., Mamán, L., and Navarro, G. (2020). New capabilities of Sentinel-2A/B satellites combined with in situ data for monitoring small harmful algal blooms in complex coastal waters. Sci. Rep. 10, 1-14. doi: 10.1038/s41598-020-65600-1

CayeCaulker.org (2020). Belize Travels, Lodging, Diving, Guides, Mayan Tours, Fishing, Hotels and Resorts, Paradise for Scuba, Vacation, Beaches Relaxing, Fishing Tourism, Vacations, Adventures. Available online at: https://cayecaulker. org/ (accessed December 30, 2020).

Cherif, E. K., Vodopivec, M., Mejjad, N., Esteves, J. C. G., and Simonovi ${ }^{2}$, S. (2020). COVID-19 pandemic consequences on coastal water. Water 12:2638.

Cherrington, E. A., Griffin, R. E., Anderson, E. R., Hernandez Sandoval, B. E., Flores-Anderson, A. I., Muench, R. E., et al. (2020). Use of public Earth observation data for tracking progress in sustainable management of coastal forest ecosystems in Belize, Central America. Remote Sens. Environ. 245:111798. doi: $10.1016 /$ j.rse.2020.111798

Cherrington, E. A., Hernandez, B. E., Trejos, N. A., Smith, O. A., Anderson, E. R., Flores, A. I., et al. (2010). Identification of Threatened and Resilient Mangroves in the Belize Barrier Reef System. Panama: CATHALAC.

Claudino-Sales, V. (2019). "Belize barrier reef system, Belize," in Coastal World Heritage Sites. Coastal Research Library, Vol. 28, (Dordrecht: Springer). doi: 10.1007/978-94-024-1528-5_66

Coastal Zone Management Authority and Institute [CZMAI] (2016). Belize integrated coastal zone management plan: the vision for our coast (ICZMP). Minsitry Agric. For. Fish. Environ. Sustain. Dev. 265, 1-265.

Contreras-Silva, A. I., Tilstra, A., Migani, V., Thiel, A., Pérez-Cervantes, E., Estrada-Saldívar, N., et al. (2020). A meta-analysis to assess long-term spatiotemporal changes of benthic coral and macroalgae cover in the Mexican Caribbean. Sci. Rep. 10, 1-12. doi: 10.1038/s41598-020-65801-8

Cooper, E., Burke, L., and Bood, N. (2009). Coastal Capital: Economic Contribution of Coral Reefs and Mangroves to Belize. Washington, DC: World Resourse Institute, 53.

Correa-Ramirez, M., Rodriguez-Santana, Á, Ricaurte-Villota, C., and Paramo, J. (2020). The Southern Caribbean upwelling system off Colombia: water masses and mixing processes. Deep. Res. Part I Oceanogr. Res. Pap. 155:103145. doi: 10.1016/j.dsr.2019.103145

De'ath, G., and Fabricius, K. (2010). Water quality as a regional driver of coral biodiversity and macroalgae on the Great Barrier Reef. Ecol. Appl. 20, 840-850.

Diedrich, A. (2007). The impacts of tourism on coral reef conservation awareness and support in coastal communities in Belize. Coral Reefs 26, 985-996. doi: $10.1007 / \mathrm{s} 00338-007-0224-\mathrm{z}$
Dutta, V., Dubey, D., and Kumar, S. (2020). Cleaning the River Ganga: Impact of lockdown on water quality and future implications on river rejuvenation strategies. Sci. Total Environ. 743:140756. doi: 10.1016/j.scitotenv.2020.140756

Eckert, R. J., Studivan, M. S., and Voss, J. D. (2019). Populations of the coral species Montastraea cavernosa on the Belize Barrier Reef lack vertical connectivity. Sci. Rep. 9, 1-11. doi: 10.1038/s41598-019-43479-x

Elliott, M., Day, J. W., Ramachandran, R., and Wolanski, E. (eds). (2019). "Chapter 1 - A synthesis: what is the future for coasts, estuaries, deltas and other transitional habitats in 2050 and beyond?," in Coasts and Estuaries (Amsterdam: Elsevier), 1-28. doi: 10.1016/B978-0-12-814003-1.00001-0

Emrich, K., Martinez-Colon, M., and Alegria, H. (2017). Is untreated sewage impacting coral reefs of Caye Caulker, Belize? J. Foraminifer. Res. 47, 20-33. doi: $10.2113 /$ gsjfr.47.1.20

Espinoza-Avalos, J., Islebe, G. A., and Hernandez-Arana, H. A. (2009). "El sistema ecológico de la bahía de Chetumal," in Corozal: Costa Occidental Del Mar Caribe, eds H. A. H.-A. J. Espinoza-Avalos and G. A. Islebe (Lerma Campeche: ECOSUR).

FleetMon (2020). Port of Barranco, Belize - Arrivals, Schedule and Weather Forecast. Available online at: https://www.fleetmon.com/ports/barranco_bzbar_14265/ ?language $=$ en (accessed December 30, 2020).

Freitas, L. M., Oliveira, M., de, D. M., Leão, Z. M. A. N., and Kikuchi, R. K. P. (2019). Effects of turbidity and depth on the bioconstruction of the Abrolhos reefs. Coral Reefs 38, 241-253. doi: 10.1007/s00338-019-01770-3

García-Sais, J. R., Williams, S. M., and Amirrezvani, A. (2017). Mortality, recovery, and community shifts of scleractinian corals in Puerto Rico one decade after the 2005 regional bleaching event. PeerJ 2017:e3611. doi: 10.7717/peerj.3611

Garg, V., Aggarwal, S. P., and Chauhan, P. (2020). Changes in turbidity along Ganga River using Sentinel-2 satellite data during lockdown associated with COVID-19. Geomat. Nat. Hazards Risk 11, 1175-1195. doi: 10.1080/19475705. 2020.1782482

Gibson, J., McField, M., and Wells, S. (1998). Coral reef management in Belize: an approach through integrated coastal zone management. Ocean Coast. Manag. 39, 229-244. doi: 10.1016/S0964-5691(98)00007-6

Gischler, E., and Hudson, J. H. (2004). Holocene development of the Belize Barrier Reef. Sediment. Geol. 164, 223-236. doi: 10.1016/j.sedgeo.2003.10. 006

Glavovic, B. C. (2017). "Coasts," in International Encyclopedia of Geography: People, the Earth, Environment and Technology, eds D. Richardson, N. Castree, M. F. Goodchild, A. Kobayashi, W. Liu, and R. A. Marston. doi: 10.1002/ 9781118786352.wbieg0817

Gómez, R. A. (2014). Spectral reflectance analysis of the Caribbean Sea. Geofis. Int. 53, 385-398. doi: 10.1016/S0016-7169(14)70073-X

Government of Belize Press Office (2020a). COVID-19 - Alert Regarding Border Closures. Available online at: https://www.pressoffice.gov.bz/covid-19-alertregarding-border-closures/ (accessed December 17, 2020).

Government of Belize Press Office (2020b). State of Emergency Declared for Ambergris Caye. Belmopan: Government of Belize Press Office. (accessed December 5, 2020).

Government of Belize Press Office (2020c). The Philip Goldson International Airport Successfully Reopens. 1-2. Available online at: https://www.pressoffice. gov.bz/the-philip-goldson-international-airport-successfully-reopens/ (accessed December 28, 2020).

Guimarais, M., Zúñiga-Ríos, A., Cruz-Ramírez, C. J., Chávez, V., Odériz, I., van Tussenbroek, B. I., et al. (2021). The conservational state of coastal ecosystems on the mexican caribbean coast: environmental guidelines for their management. Sustain 13, 1-25. doi: 10.3390/su13052738

Gupta, P., Christopher, S. A., Wang, J., Gehrig, R., Lee, Y., and Kumar, N. (2006). Satellite remote sensing of particulate matter and air quality assessment over global cities. Atmos. Environ. 40, 5880-5892. doi: 10.1016/j.atmosenv.2006.03. 016

Haines, S. (2019). Managing expectations: articulating expertise in climate services for agriculture in Belize. Clim. Change 157, 43-59. doi: 10.1007/s10584-0182357-1

Helmuth, B., Leichter, J. J., Rotjan, R. D., Castillo, K. D., Fieseler, C., Jones, S., et al. (2020). High resolution spatiotemporal patterns of seawater temperatures across the Belize Mesoamerican Barrier Reef. Sci. Data 7, 1-6. doi: 10.1038/ s41597-020-00733-6 
Ho, J. C., Stumpf, R. P., Bridgeman, T. B., and Michalak, A. M. (2017). Using landsat to extend the historical record of lacustrine phytoplankton blooms: a Lake Erie case study. Remote Sens. Environ. 191, 273-285. doi: 10.1016/j.rse. 2016.12.013

Hoegh-Guldberg, O., Mumby, P. J., Hooten, A. J., Steneck, R. S., Greenfield, P., Gomez, E., et al. (2007). Coral reefs under rapid climate change and ocean acidification. Science 318, 1737-1742. doi: 10.1126/science.1152509

Kuhn, C., de Matos Valerio, A., Ward, N., Loken, L., Sawakuchi, H. O., Kampel, M., et al. (2019). Performance of Landsat- 8 and Sentinel-2 surface reflectance products for river remote sensing retrievals of chlorophyll-a and turbidity. Remote Sens. Environ. 224, 104-118. doi: 10.1016/j.rse.2019.01. 023

López, R., López, J. M., Morell, J., Corredor, J. E., and Del Castillo, C. E. (2013). Influence of the Orinoco River on the primary production of eastern Caribbean surface waters. J. Geophys. Res. Ocean. 118, 4617-4632. doi: 10.1002/jgrc. 20342

Macintyre, I. G., Toscano, M. A., Feller, I. C., and Faust, M. A. (2009). Decimating mangrove forests for commercial development in the Pelican cays, Belize: long-term ecological loss for short-term gain? Smithson. Contrib. Mar. Sci. 25, 281-290.

Maidens, J., and Burke, L. (2005). Belize Coastal Threat Atlas. Washington, DC: World Resourse Institute.

Martínez, M. L., Intralawan, A., Vázquez, G., Pérez-Maqueo, O., Sutton, P., and Landgrave, R. (2007). The coasts of our world: ecological, economic and social importance. Ecol. Econ. 63, 254-272. doi: 10.1016/j.ecolecon.2006.10.022

Martínez-Castillo, V., Paola Rodríguez-Troncoso, A., Reyes-Bonilla, H., AguilarCruz, C. A., and Rangel-Dávalos, C. (2020). Reproduction of the endangered endemic saffron coral to the Gulf of California Porites sverdrupi (Anthozoa: Scleractinia): implications for its long-term maintenance. Helgol. Mar. Res. 74:6. doi: 10.1186/s10152-020-00538-5

Mélin, F., and Vantrepotte, V. (2015). How optically diverse is the coastal ocean? Remote Sens. Environ. 160, 235-251. doi: 10.1016/j.rse.2015.01.023

Mendoza, W. G., Zika, R. G., Corredor, J. E., Morrel, J., Ko, D. S., and Mooers, C. N. K. (2009). Developmental strategy for effective sampling to detect possible nutrient fluxes in oligotrophic coastal reef waters in the Caribbean. J. Oper. Oceanogr. 2, 35-47. doi: 10.1080/1755876X.2009.11020107

Mishra, D. R., Kumar, A., Muduli, P. R., Equeenuddin, S. M., Rastogi, G., Acharyya, T., et al. (2020). Decline in phytoplankton biomass along indian coastal waters due to COVID-19 lockdown. Remote Sens. 12:2584. doi: 10.3390/rs12162584

Mishra, D. R., Narumalani, S., Rundquist, D., and Lawson, M. (2005a). Characterizing the vertical diffuse attenuation coefficient for downwelling irradiance in coastal waters: implications for water penetration by high resolution satellite data. ISPRS J. Photogramm. Remote Sens. 60, 48-64. doi: 10.1016/j.isprsjprs.2005.09.003

Mishra, D. R., Narumalani, S., Rundquist, D., and Lawson, M. (2005b). Highresolution ocean color remote sensing of benthic habitats: a case study at the Roatan Island, Honduras. IEEE Trans. Geosci. Remote Sens. 43, 1592-1603. doi: 10.1109/TGRS.2005.847790

Mishra, D. R., Narumalani, S., Rundquist, D., Lawson, M., and Perk, R. (2007). Enhancing the detection and classification of coral reef and associated benthic habitats: a hyperspectral remote sensing approach. J. Geophys. Res. 112:C08014. doi: 10.1029/2006JC003892

Mishra, R. K., Agarwal, A., and Shukla, A. (2021). Predicting ground level PM 2.5 concentration over Delhi using Landsat 8 satellite data. Int. J. Remote Sens. 42, 827-838. doi: 10.1080/2150704X.2020.1832279

Morales-Vela, B., Olivera-Gómez, D., Reynolds, J. E., and Rathbun, G. B. (2000). Distribution and habitat use by manatees (Trichechus manatus manatus) in Belize and Chetumal Bay. Mexico. Biol. Conserv. 95, 67-75. doi: 10.1016/S00063207(00)00009-4

Murray, R. (2020). A governance analysis of three MPAs in Belize: conservation objectives compromised by tourism development priorities? Mar. Policy 2020:104243. doi: 10.1016/j.marpol.2020.104243

Nanda, D., Mishra, D. R., and Swain, D. (2020). COVID-19 lockdowns induced land surface temperature variability in mega urban agglomerations in India. Environ. Sci. Process. Impacts 23, 144-159. doi: 10.1039/D0EM00358A

NASA Global Modeling and Assimilation Office (2020). MERRA-2. Available online at: https://gmao.gsfc.nasa.gov/reanalysis/MERRA-2/ (accessed December 30, 2020).
News Belize (2020). Big Business At Big Creek Port. Available online at: http://www.7newsbelize.com/sstory.php?nid=34664 (accessed December 18, 2020).

Niroumand-Jadidi, M., Bovolo, F., Bruzzone, L., and Gege, P. (2020). Physics-based bathymetry and water quality retrieval using planetscope imagery: impacts of 2020 COVID-19 lockdown and 2019 extreme flood in the Venice lagoon. Remote Sens. 12:2381. doi: 10.3390/RS12152381

Patel, P. P., Mondal, S., and Ghosh, K. G. (2020). Some respite for India's dirtiest river? Examining the Yamuna's water quality at Delhi during the COVID-19 lockdown period. Sci. Total Environ. 744:140851. doi: 10.1016/j.scitotenv.2020. 140851

Port of Big Creek (2020). Port of Big Creek. Available online at: http:// www.portofbigcreek.com/\#smoothscroll-facts-module (accessed December 18, 2020).

R Core Team (2020). R: A Language and Environment for Statistical Computing. Vienna: R Core Team.

Renaud, L. (2020). Cruise tourism threatens to drive land speculation and displacement in Belize. NACLA Rep. Am. 52, 442-447. doi: 10.1080/10714839. 2021.1840177

Reyes, T., Gilchrist, H., Lacasse, O., Peiffer, F., Duffy, H., and Druskat, A. (2019). Five Years in Bacalar Chico Marine Reserve?: an Evaluation of Reef Health and Reserve Effectiveness Between, Vol. 44. London: Blue Ventures, 105. Blue Ventures Conservation Report.

Rume, T., and Islam, S. M. D. U. (2020). Environmental effects of COVID-19 pandemic and potential strategies of sustainability. Heliyon 6:e04965. doi: 10. 1016/j.heliyon.2020.e04965

Rutz, C., Loretto, M. C., Bates, A. E., Davidson, S. C., Duarte, C. M., Jetz, W., et al. (2020). COVID-19 lockdown allows researchers to quantify the effects of human activity on wildlife. Nat. Ecol. Evol. 4, 1156-1159. doi: 10.1038/s41559020-1237-z

Shi, W., and Wang, M. (2010). Characterization of global ocean turbidity from moderate resolution imaging Spectroradiometer ocean color observations. J. Geophys. Res. 115:C11022. doi: 10.1029/2010JC006160

Soto, I., Andréfouët, S., Hu, C., Muller-Karger, F. E., Wall, C. C., Sheng, J., et al. (2009). Physical connectivity in the Mesoamerican barrier reef system inferred from 9 years of ocean color observations. Coral Reefs 28, 415-425. doi: 10.1007/ s00338-009-0465-0

Sweetman, B. M., Foley, J. R., and Steinberg, M. K. (2019). A baseline analysis of coastal water quality of the port Honduras marine reserve, Belize: a critical habitat for sport fisheries. Environ. Biol. Fish. 102, 429-442. doi: 10.1007/ s10641-018-0811-6

Tomlinson, M. C., Stumpf, R. P., and Vogel, R. L. (2019). Approximation of diffuse attenuation, $\mathrm{K}_{d}$, for MODIS high-resolution bands. Remote Sens. Lett. 10, 178-185. doi: 10.1080/2150704X.2018.1536301

Torregroza-Espinosa, A. C., Restrepo, J. C., Escobar, J., Pierini, J., and Newton, A. (2021). Spatial and temporal variability of temperature, salinity and chlorophyll-a in the Magdalena River mouth, Caribbean Sea. J. South Am. Earth Sci. 105:102978. doi: 10.1016/j.jsames.2020.102978

UNESCO (1996). "World heritage committee," in Proceedings of the 20th Convention concerning the Protection of the World Cultural and Natural Heritage, Baku.

United Nations (2020a). Coronavirus Disease - COVID 19 Situation Note No . 4. 1-6. Available online at: https://reliefweb.int/sites/reliefweb.int/files/resources/ COVID 19 Situation Report No 4 BELIZE Final.pdf (accessed December 9, 2020).

United Nations (2020b). Goal 14 - Conserve and Sustainably Use the Oceans, Seas and Marine Resources for Sustainable Development. Available online at: https: //sdgs.un.org/goals/goal14 (accessed December 30, 2020).

Vega Sequeda, J. C., Zea, S., and Bernal, G. (2017). Efectos de eventos oceánicos extremos en formaciones coralinas de islas del rosario, Caribe Colombiano. CICIMAR Oceán. 32:25. doi: 10.37543/oceanides.v32i1.194

Verutes, G. M., Arkema, K. K., Clarke-Samuels, C., Wood, S. A., Rosenthal, A., Rosado, S., et al. (2017). Integrated planning that safeguards ecosystems and balances multiple objectives in coastal Belize. Int. J. Biodivers. Sci. Ecosyst. Serv. Manag. 13, 1-17. doi: 10.1080/21513732.2017.1345979

Wang, J., and Christopher, S. A. (2003). Intercomparison between satellitederived aerosol optical thickness and PM2.5. Res. Lett 30:2095. doi: 10.1029/ 2003GL018174 
Warne, A. G., Webb, R. M. T., and Larsen, M. C. (2005). Water, Sediment, and Nutrient Discharge Characteristics of Rivers in Puerto Rico, and their Potential Influence on Coral Reefs. Reston: U.S. Geological Survey, 58. U.S. Geological Survey Investigation Report 2005-5206.

Wells, C. E., Alex Webb, W., Prouty, C. M., Zarger, R. K., Trotz, M. A., Whiteford, L. M., et al. (2019). Wastewater technopolitics on the southern coast of Belize. Econ. Anthropol. 6, 277-290. doi: 10.1002/sea2.12145

Wells, E. C., Zarger, R. K., Whiteford, L. M., Mihelcic, J. R., Koenig, E. S., and Cairns, M. R. (2014). The impacts of tourism development on perceptions and practices of sustainable wastewater management on the Placencia Peninsula, Belize. J. Clean. Prod. 111, 430-441. doi: 10.1016/j.jclepro.2014.08.050

Werdell, P. J., and Bailey, S. W. (2005). An improved in-situ bio-optical data set for ocean color algorithm development and satellite data product validation. Remote Sens. Environ. 98, 122-140. doi: 10.1016/j.rse.2005.07.001

Young, C. A. (2008). Belize's Ecosystems: threats and challenges to conservation in Belize. Trop. Conserv. Sci. 1, 18-33. doi: 10.1177/194008290800100102

Yunus, A. P., Masago, Y., and Hijioka, Y. (2020). COVID-19 and surface water quality: improved lake water quality during the lockdown. Sci. Total Environ. 731:139012. doi: 10.1016/j.scitotenv.2020.139012
Zhang, C., Shi, Z., Zhao, J., Zhang, Y., Yu, Y., Mu, Y., et al. (2021). Impact of air emissions from shipping on marine phytoplankton growth. Sci. Total Environ. 769:145488. doi: 10.1016/j.scitotenv.2021.145488

Zheng, Z., Ren, J., Li, Y., Huang, C., Liu, G., Du, C., et al. (2016). Remote sensing of diffuse attenuation coefficient patterns from Landsat 8 OLI imagery of turbid inland waters: a case study of Dongting Lake. Sci. Total Environ. 573, 39-54. doi: 10.1016/j.scitotenv.2016.08.019

Conflict of Interest: The authors declare that the research was conducted in the absence of any commercial or financial relationships that could be construed as a potential conflict of interest.

Copyright (C) 2021 Callejas, Lee, Mishra, Felgate, Evans, Carrias, Rosado, Griffin, Cherrington, Ayad, Rudresh, Page and Jay. This is an open-access article distributed under the terms of the Creative Commons Attribution License (CC BY). The use, distribution or reproduction in other forums is permitted, provided the original author(s) and the copyright owner(s) are credited and that the original publication in this journal is cited, in accordance with accepted academic practice. No use, distribution or reproduction is permitted which does not comply with these terms. 